\title{
Analysis of Bus Trans Semarang Corridor VI through Monitoring System and Passenger Information System
}

\author{
Mudjiastuti Handajani, Andi Kuriniawan, and Harmini
}

\begin{abstract}
The Smart City being expedient and reliable is safe, convenient, cheap, regular, scheduled as well as modern city transportation system. The Trans Semarang buses run simultaneously on public roads, there is bound to be inaccurate arrival time information. Consequently, there is the need for a system that can provide adequate and accurate information in real time, in the form of monitoring system and passenger information. Each bus boasts of a GPS tracker unit, GSM, and a micro controller to ascertain the position and measure the speed of the bus. The central control unit has a receiver and GUI with a real time display that is joined with the shelter unit. Therefore, prospective passengers have a firsthand knowledge of the movements of the bus in real time, the number of passengers it carries and the precise location of the bus. The focus of this research is on Trans Semarang Bus Corridor VI UNDIP-UNNES department. The needed data is collected on a weekdays. The load factor is $37-47 \%$, and the average headway is 5-7 minutes. The objective of this study is to create a real time monitoring system and Passenger Information System at two stops (Elizabeth and Kesatrian).
\end{abstract}

Index Terms - Monitoring System, Passenger Information System, Rapid Transit Bus, Smart City.

\section{INTRODUCTION}

$\mathrm{S}_{\mathrm{m}}$ Semarang's Smart City program is expected to be a metropolitan system of transportation that is fortified with the awareness of the environment. These buses are expected to be is reliable, safe, comfortable, cheap, well organized, scheduled and sophisticated and well-managed [1]. According to research, it was found out that public transportation in Semarang City currently serves not more than $7 \%$ of the population. In order to motivate passengers to use public transportation (Semarang rapid-transit buses), there is the provision of the real time arrival information. This will enable the users to plan their departure and arrival time to their respective destinations with ease and accuracy. However, this good intent faces several challenges since Trans Semarang

M. Handajani is with the Civil Engineering, Engineering Faculty, Universitas Semarang, Semarang,, Indonesia.

A. Kurniawan is with the Electrical Engineering, Engineering Faculty, Universitas Semarang, Semarang, Indonesia.

Harmini is with the Electrical Engineering, Engineering Faculty, Universitas Semarang, Semarang, Indonesia.
Buses also ply public roads that other vehicles make use of (mixed traffic). This results in a situation where their speed cannot be accurately measured, leading to having inaccurate arrival time information.

Therefore, there is an absolute need to have a Monitoring System and a Passenger Information System which tend to provide the departure schedule information to the users and operator, so that users of public means of transportation will well-informed so as to easily plan their travel well. Hence, this will eventually encourage members of the community to use mass public transportation (Semarang rapid-transit buses) instead of private cars. By changing the urban transportation system, this changes people's journey, with very different risks for the future of the city [2]. Furthermore, this will go a long way to reduce the volume of vehicles/traffic in Semarang City road as well as lessen the usage of non-renewable fossil based fuel oil.

This aim of this study is to build a Monitoring System and Passenger Information System for Semarang Rapid-Transit Buses Corridor VI for UNDIP-UNNES Direction. Besides providing the accurate time arrival/departure information of buses, they may also provide a reliable and modern transportation infrastructure. Besides, they may also help to create ideas that will result into better urban transportation system [3] and to accomplish Smart Transportation towards Smart City for Indonesian cities, especially Semarang City.

\section{LITERATURE REVIEW}

A highly populated city should make use of public mass transportation [4], given that population density and city transportation are the bases to control the usage of fuel oil. A relationship model of transportation system and fuel oil which makes use of a Partial Least Square (PLS) reveals that the fuel oil consumed by buses has lower influence $(0.213)$ than the fuel oil personal vehicles consumed $(0.293)$ because fewer people make use of public buses [5-7].

The real time Monitoring System and Passenger Information System for buses are possible to be put into operation by installing GPS on every City Bus. The Monitoring System and Passenger Information System are separately designed to pinpoint locations of buses in real time. Also, they are fortified with GPS tracker unit to gather information about the location of buses at the unit control 
centers. The system of monitoring makes use of web server to keep an eye on buses in real time and mobile application for buses users [8]. After the research carried out [9], the results reveal that it is possible for mass transportation to operate successfully if the land use is compact (mix used). The high level of land use compactness determines the reduction in fuel oil consumption/capita. Enhancing efficient fuel oil usage towards viable transportation may be achieved by: changing from using personal vehicles to using reliable (equipped with the environmental insight, safe, comfortable, cheap, well organized and scheduled) and modern public mass transportation. Finally, there is the need to reevaluate and rearrange routes that overlap [10].

\section{RESEARCH METHOD}

This research contains three stages, (1) Preparation stage, which includes applying for license and collaborating with the Municipal Transportation Department of Semarang and Industry Partner, PT. INOVASI CYBER INVESTAMA, carrying out field survey to gather the primary data of Semarang rapid-transit buses (route, speed, boarding alighting, headway, distance between shelters, shelter condition and questionnaire) and secondary data (number of vehicles, schedule, coordinate, Bus route, number of shelters, shelter condition, Bus type), (2) Implementation Stage (analysis on the system of Semarang rapid- transit buses), which includes designing, making and performing trial of the Monitoring System and Passenger Information System, (3) Installation and Implementation of Monitoring System to locate Semarang rapid-transit buses at the control centers and Passenger Information System (at 2 transit points/ shelters which are the interconnections of Semarang rapid-transit buses from various destinations). The Research Flow Chart may be examined in Fig.1 below:

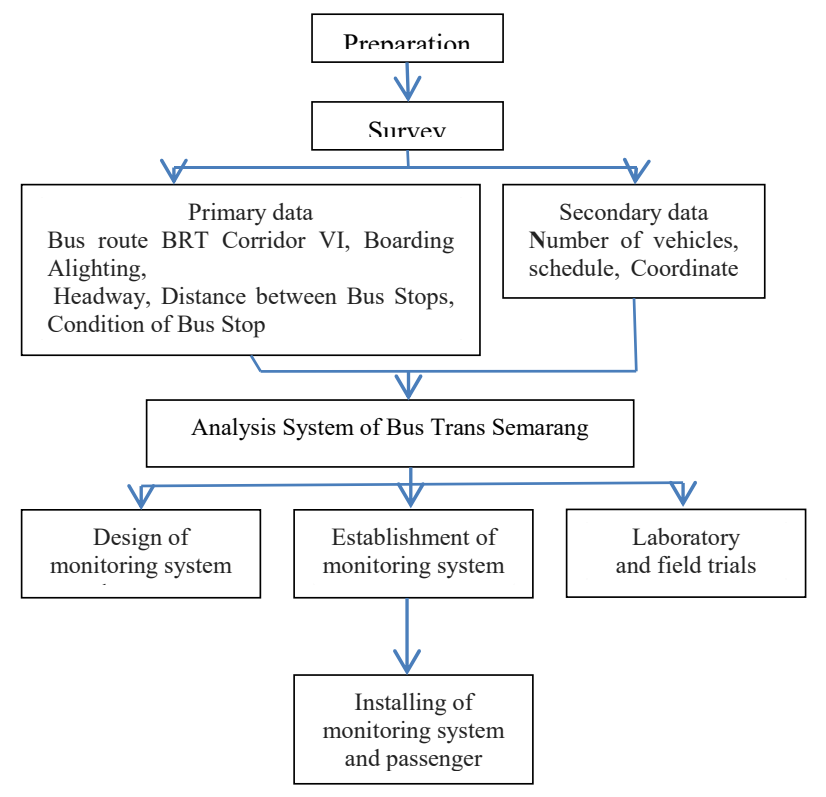

Fig.1 . Research Flow Chart

\section{RESEARCH RESUltS}

\subsection{Condition of rapid transit buses corridor VI}

The route of Rapid Transit Buses (BRT) Corridor VI UNDIP-UNNES destination which is an educational way has different route in its round trip. The monitoring system is installed at the Elizabet and Ksatrian transit points. The sketch and research outline may be viewed in Fig.2.

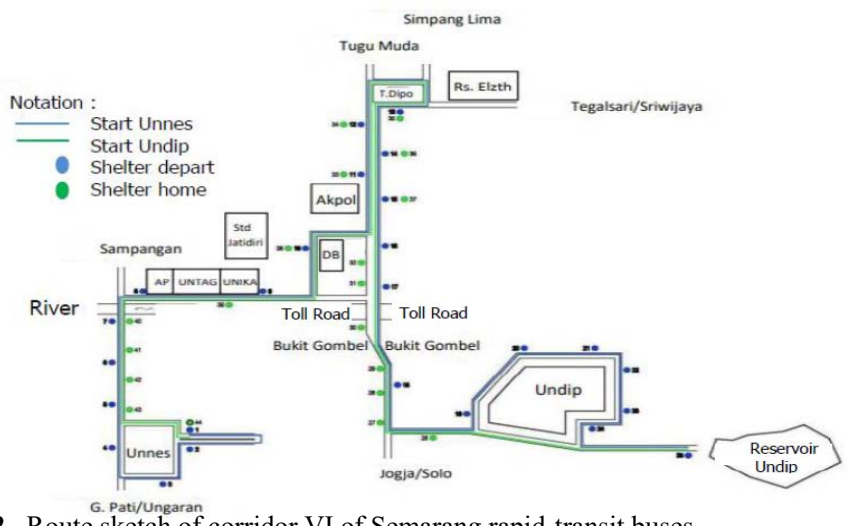

Fig.2 . Route sketch of corridor VI of Semarang rapid-transit buses

The average speed is obtained by comparing the travelled distance and travel time. Weekdays, short days and holidays have various results of speed. With the travelled distance of $20.1 \mathrm{~km}$, the UNDIP-UNNES route has the travel time on weekdays of 83 minutes at day peak with an average speed of $15.95 \mathrm{~km} / \mathrm{hour}$, the travel time on short days of 95 minutes with an average speed of $18.97 \mathrm{~km} /$ hour and the travel time on holidays of 57 minutes with an average speed of 24.53 $\mathrm{km} /$ hour.

The UNNES-UNDIP route has the travelled distance of 22.3 $\mathrm{km}$, thus the BRT Corridor VI's total distance (round trip) is $42.4 \mathrm{~km}$. The travel time on weekdays is 93 minutes at day peak with an average speed of $22.37 \mathrm{~km} /$ hour, the travel time on short days is 90 minutes with an average speed of 19.45 $\mathrm{km} /$ hour and the travel time on holidays is 84 minutes with an average speed of $23.15 \mathrm{~km} /$ hour.

The number of passengers of BRT Corridor VI on weekdays, short days and holidays which is calculated at morning peak, day peak and afternoon peak may be viewed in Fig.3.

According to the data in Fig.3, the highest number of passengers of BRT Corridor VI is on weekdays (Monday to Thursday) of $47 \%$ with most of the passengers are students. The lowest number of passengers is on holidays (Saturday and Sunday) of $20 \%$. As one performance parameter of public transportation, the load factor is standardized by the Director General of Land Transportation of $60 \%-80 \%(0.6-0.8)$ and a reserve of $\pm 30 \%( \pm 0.3)$ to accommodate possible additional passengers. The load factor of Semarang Rapid-Transit Buses Corridor VI is $37-47 \%$. The load factor of Semarang RapidTransit Buses is shown in Fig. 4 below. 

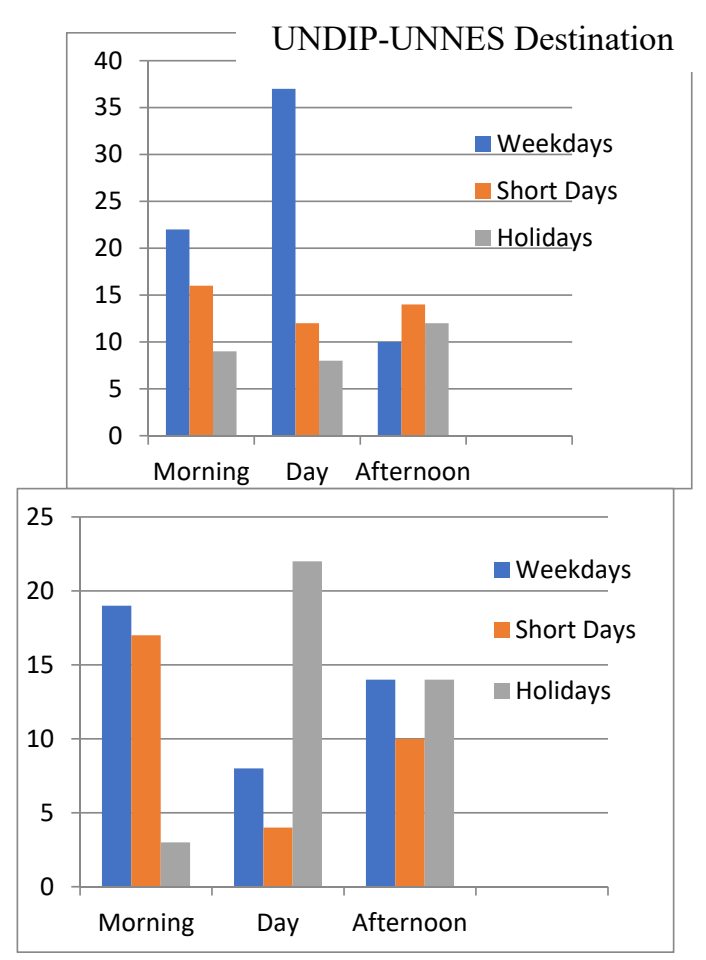

Fig.3 . Number of passengers of brt corridor VI

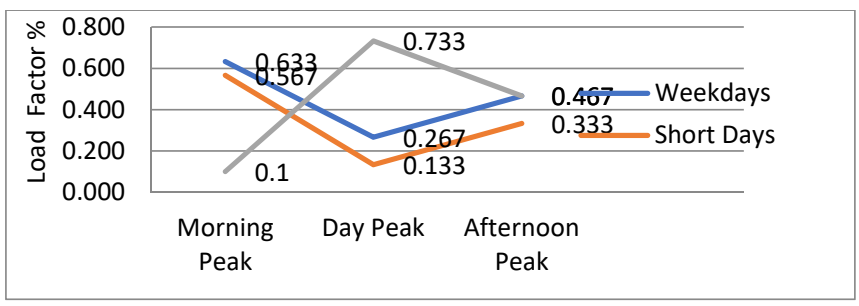

a) Chart of Load Factor of UNDIP-UNNES Destination

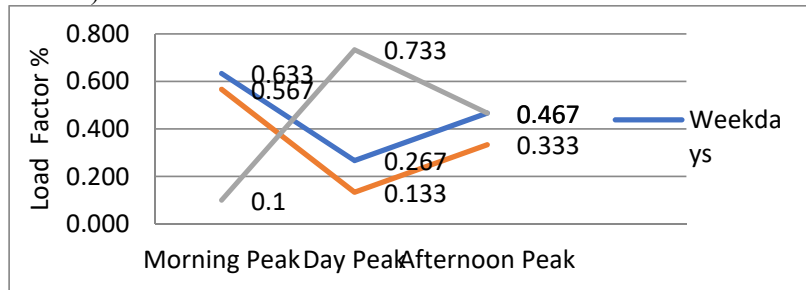

b) Chart of Load Factor of UNNES-UNDIP Destination

Fig.4 . Chart of Load Factor of BRT corridor VI Semarang

The highest average value of load factor is on weekdays (1.233) and the load factor on holidays is lower (0.1). The factor that causes the load factor value on holidays lower is that the route used by BRT Corridor VI is an educational way that the students use to go to campus (Monday - Friday), thus the load factor on holidays or the number of BRT passengers is low. The Buses Headway is averagely 5 to 7 minutes, as measured from the interval of consecutive arrival of a Bus with the next Bus on the same route. The waiting time of until the next Bus is 3 to 7 minutes. Most bus stops are open that it feels hot and inconvenience. 2 shelters are in closed condition, which are taken as the place for installation of research tools in the form of real time Passenger Information System product ts .. of arrival and departure s UNNES-UNDIP Destination ffectively improve public services.

The Monitoring System is placed at the office of Municipal Transportation Department of Semarang and the real time Passenger Information System will be placed at the Elizabeth shelter and Kesatrian shelter. Both shelters take role as the transit units that serve Corridor II, III and IV because of its strategic location and they are shelters with high demand proportion. The shelters condition may be viewed in Fig. 5 .

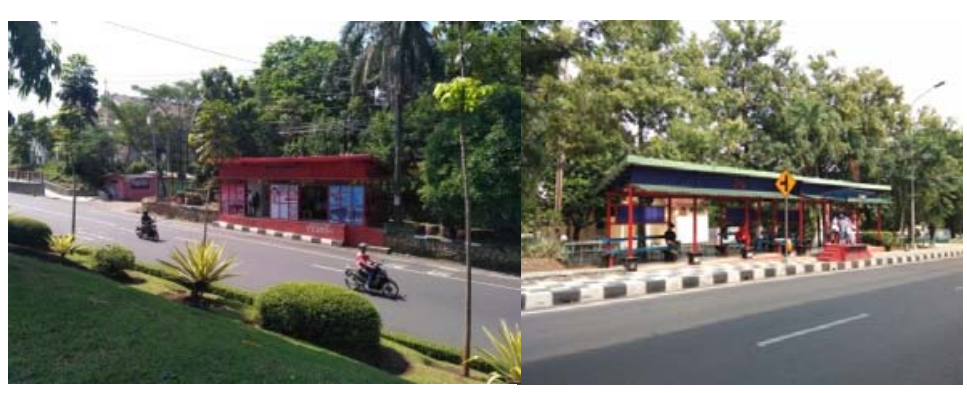

(b) Figure of Kesatrian Shelter

(a) Figure of Elizabeth Shelter of brt corridor VI
Location of shelter point with high potential demand for Corridor VI may be viewed in Fig.6.

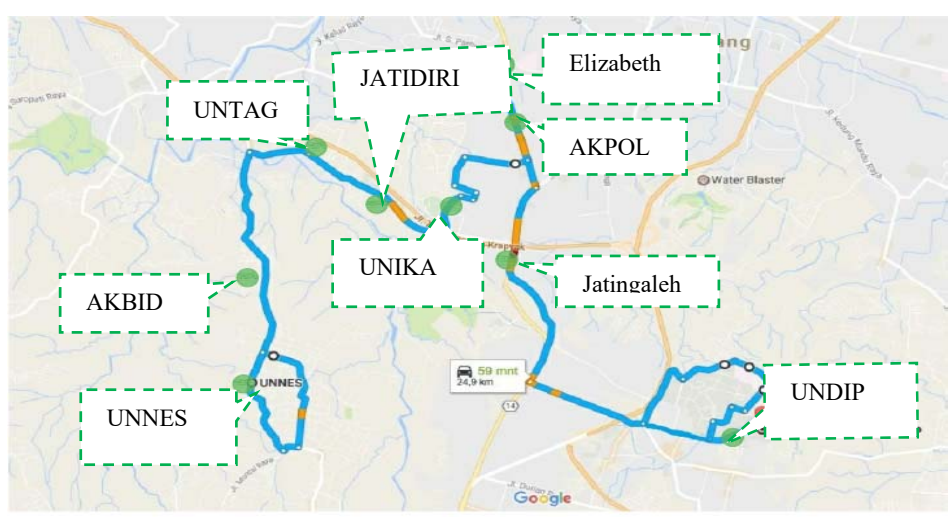

Fig.6 . Location of shelter points with high potential demand for BRT corridor VI

This location potentially causes traffic jam on the roads in the future. The data of headway, distance between shelters, passenger waiting time, shelter location, location of BRT Bus Stop and Bus location will be used for the Monitoring System and Passenger Information System of Semarang Rapid-Transit Buses Corridor VI. 


\subsection{Monitoring system and Passenger information system}

The devices used for the monitoring system and Passenger Information System are GPS, Server and Display monitor. The system consists of three critical modules:

1. Bus Unit

There are one unit of GPS tracker module, one unit of GSM modem module and one unit of micro controller module which will collect the data of all sensor inputs in the form of Bus position, Bus speed and number of passengers as well as emergency signal.

2. Central Control Unit

This unit receives information from Bus unit in the form of position, speed and number of passengers. CCU constitutes one unit of receiver module, one unit of micro controller and emergency receiver to monitor Bus condition in real time. CCU also provides a real time GUI monitoring which will be received equivalent to ClientSide Application.

3. Client-Side Application

The client-side application contains a receiver unit and GUI/ Monitoring which are displayed in real time at each shelter point. The client-side application can be directly observed by potential passengers regarding the estimated time a Bus will arrive and the capacity of the Bus occupied by passengers.

The Monitoring System and Passenger Information System devices of BRT Corridor VI may be viewed in Fig.7.

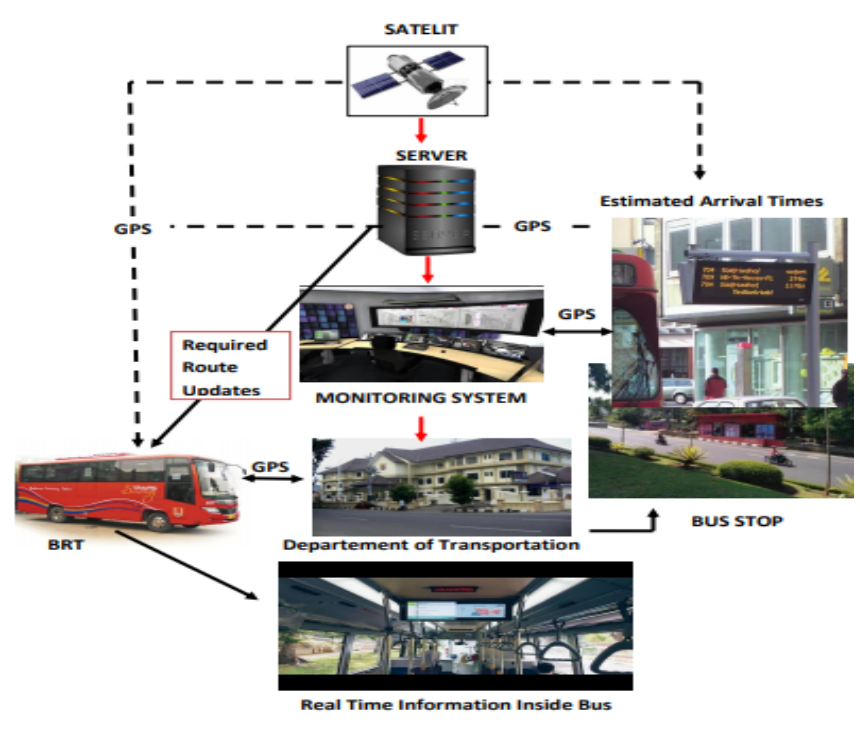

Fig.7. Monitoring system and passenger information system devices

In the Monitoring System and Passenger Information System devices, Buses have GPS device installed to send their coordinate in the form of latitude and longitude to the main server. The server receives signal from satellite, thus it may locate the Bus position through the installed GPS. The GPS transceiver is in the form of Loggers data, Pullers or Pushers data. This device may receive GPS information and regularly send the data to the server, and then the server analyzes the data it has received. At every point, the server provides the location and the whole information it has received, saved and managed.

The server is the intermediary between Bus module and user/passenger module. The database consists of real-time information such as, Bus route, actual arrival/departure time and Bus real time location. The GPS module on the Bus sends data in the form of latitude and longitude and then they are saved in the computer system. At the same time, a Bus user/passenger inputs the source and destination as well as Bus number which will be located. User/passenger module's searching results in Bus's whole routes when the Bus is travelling and will search for the range from the user/passenger to the Bus's current location. If the Bus is within reach, the searching may also cover the Bus's inner condition and examine that the Bus is active within certain range. If the Bus location matches the passenger's source location, the Bus actively calculate the time needed to reach the passenger location. In addition, the computer system will update the Bus's latitude and longitude Bus. The GUI/ monitoring system will display the Bus's location and arrival time information to the user/passenger. This process repeats the cycle for each searching made by a user/passenger.

The system is operated via a GPS installed on the Bus. First, the Receiver receives signal from satellite and then the latitude and longitude will be determined. This system employs an Automatic Vehicle Location (AVL). By using an AVL, The Bus's geographical location may be determined and sent to the server remotely. With transmission and GPS mechanism, the location may be determined and received via satellite. After receiving the location, the tracking information will be sent via GSM wireless system. A remote user/passenger may also access the Bus data based on Bus availability and user/passenger's destination. The proposed system may inform the Bus's exact location. The tracking/GPS technology is useful to track and monitor Bus's position.

These systems will provide actual Buses departure and arrival information. The Monitoring System and Passenger Information System may be an effort to provide a more reliable and modern transportation infrastructure. Thus, they may help plan a better urban transportation system as well as to realize Smart Transportation towards Smart City for Indonesian cities, especially Semarang City.

\subsection{Monitoring system configuration}

The monitoring system configuration is used to display the data of coordinate of Passenger Information System pursuant to Fig.8. The system can be monitored via web https://.eriset.org/riset/mrt/. 


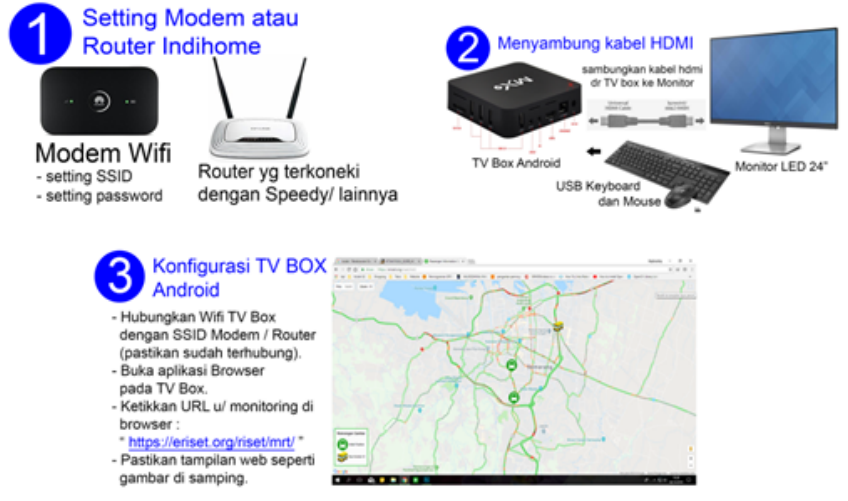

Fig.8. Configuration of monitoring system and passenger information system

\section{CONCLUSIONS}

The Monitoring System and Passenger Information System consist of 2 (two) main components, which are: (a) transmitter (Bus); (b) receiver, located at Bus shelter and center monitoring, consisting of Rapid-Transit Buses, Central Control Unit and Client Side Application. These systems will be installed at Elizabeth shelter and Kesatrian shelter. In addition to their closed condition, which will improve security and comfort, both shelters serve as interconnection shelter for corridors II, III and IV because of its strategic location and they are shelters with high demand proportion.

\section{ACKNOWLEDGEMENT}

The writer thanks the DIKTI for giving an opportunity and its support in the making of GRANT of Applied Featured College Research.

\section{REFERENCES}

[1] Mudjiastuti Handajani, "Evaluasi Angkutan Umum Kota Semarang Ditinjau dari sisi Teknis, Ekonomi dan Lingkungan (Studi kasus Rute Penggaron - Mangkang Semarang)," Thesis, MSTT-UGM, Jogyakarta, 1998.

[2] Sukarto Haryono, "Transportasi Perkotaan dan Lingkungan," Jurnal Teknik Sipil Vol 3, No.2, 2006.

[3] Mudjiastuti Handajani, "Kebutuhan Model Valuasi Lingkungan Bagi Kegiatan Transportasi," Media Komunikasi Teknik Sipil th 15 No 2 Juni 2007, Terakreditasi 23a/Dikti/Kep/2004, Penerbit PII dan BMPTSSI

[4] Mudjiastuti Handajani, "Kebutuhan Permodelan Sistem Transportasi Nasional," th 15 No 3 ISSBN 0854-1809, 2007, Terakreditasi.

[5] Andre Dantas, Susan Krumdieck, and Shannon Page, "Risk of Energy Constrained Activity-Transport System (RECATS)," Journal of The Eastern Asia Society for Transportation Studies, Vol.7,1154-1168, 2007.

[6] Departmen Perhubungan Darat, "Perencanaan Umum Pengembangan Transportasi Massal di Pulau Jawa," Jakarta, 2008.

[7] Advait, V. and Kevin,T., "The Role of VGI in Modelling Future Energy Demand, Department of Earth and Atmospheric Sciences, 550 Stadium Mall Drive," Purdue University, West Lafayette, USA, 2009.

[8] Supriyanto D., and Wijayanti A., "Kinerja Layanan Bis Kota di Kota Surabaya," Journal Transportasi, FSTPT vol 10, 2010.
[9] Mudjiastuti Handajani, "The Influence Of The Urban Transport System In Java on City Fuel," Proceeding The $4^{\text {th }}$ ASEAN Civil Engineering Conference, 2011.

[10] Mudjiastuti Handajani, "Non Linear Model City Transportation System and Control of Fuel Consumption," International Journal of Computational Engineering Research (IJCER), Vol. 2, Issue 2 pp. 228235, 2012.

[11] Mudjiastuti Handajani, "The Urban Transportation System and Fuel Consumtion of Metropolitan and large City," The 13th International Conference on QiR (Quality in Research), 2013.

[12] Mudjiastuti Handajani, "Analisis Hubungan Jumlah Penduduk dan Kepadatan Penduduk dengan BBM Transportasi Kota," Jurnal Tataloka Akreditasi Nasional ISSN 0852-7458, Vol 15 No 4 pp. 235316, 2013.

[13] Mudjiastuti Handajani, "Konsumsi Bahan Bakar Minyak Kota Semarang dan Kota Surakarta ditinjau dari Sistem transportasi dan Tipologi Kota," Jurnal Transportasi, Forum Studi Transportasi Perguruan Tinggi, Vol 13, no 3, pp. 223-232, 2013.

[14] Swati, Chandurkar, "Implementation of Real Time Bus Monitoring and Passenger Information System," International Journal of Scientific and Research Publication, Volume 3, Issue 5, May 2013, ISSN 2250-3153, 2013.

[15] Dirjen Migas Kementerian ESDM, "Cadangan Bahan Bakar Nasional," 2015.

[16] Mudjiastuti Handajani, "Pengukuhan Guru Besar Teknik Sipil, Fakultas Teknik Universitas Semarang, Solusi Hemat Bahan Bakar Minyak (BBM) Menuju Transportasi Berkelanjutan, 2016.

[17] Renstra Universitas Semarang Tahun 2016-2020 